\section{Od obserwatorów do gapiów. Kategoria bystanders i analiza wizualna'}

Roma Sendyka

TEKSTY DRUGIE 2018, NR 3, S. 117-130

DOI: $10.18318 /$ td.2018.3.7
NARODOWY PROGRAM ROZWOJU HUMANISTYKI

Artykuł powstał w ramach grantu Nieupamiętnione miejsca ludobójstwa i ich wpływ na pamięć zbiorowa tożsamość kulturowq postawyetyczne i relacje międzykulturowe we współczesnej Polsce (NPRH, nr rej. $2 \mathrm{aH} 15012183$ ).

Look at him. Tell them over there. You saw it.

Don't forget. $^{2}$

Patrz na niego. Powiedz im tam. Widziałeś to.

Nie zapomnij

W powyższym zdaniu, będącym jądrem - wyjaśnieniem źródła wezwania, zakresu zobowiązania, natury dalszych, także powojennych, działań byłego kuriera z Polski - wielogodzinnego sprawozdania Jana Karskiego, złożonego przed Claude’em Lanzmannem w 1978 roku, czasowniki „patrzeć” $i$ „powiedzieć”, „widzieć” $i$ „nie zapomnieć" połączone zostały w pary czynności koniecznie nierozłącznych i następczych. „Epoka świadków”,

1 Poniższy tekst rozwija tezy, które prezentowałam w artykule Bystanders as Visual Subjects: Onlookers, Spectators, Observers, Gawkers publikowanym w: Probing the Limits of Categorization: The Bystander in Holocaust History, ed. by Ch. Morina, K. Thijs, Berghahn Books, New York 2018 (w przygotowaniu).

2 Fragment zeznania Jana Karskiego w filmie Shoah Claude'a Lanzmanna - rozdział 7 (cz. 4). Korzystam z wydania na DVD: Shoah. Afilm by Claude Lanzmann, Videofilmexpress, 2009.

3 Zob. A. Wieviorka The Era of the Witness, transl. J. Stark, Cornell University Press, Ithaca, 2006 [1998 L'ère du temoin].

\section{Roma Sendyka}

- dr hab., pracuje w Katedrze Antropologii Literatury ¡ Badań Kulturowych WP UJ, prowadzi Ośrodek Badań nad Kulturami Pamięci. Zajmuje się teoriami badań literackich i kulturowych, w tym zwłaszcza badaniami nad kulturą wizualną i kulturami pamięci. Kieruje grantem Awkward Objects of Genocide w ramach projektu TRACES (Horyzont2020) oraz zespołem realizującym grant Nieupamiętnione miejsca ludobójstwa (NPRH). Kontakt: roma.sendyka@uj.edu.pl 
przywilejując mowę i tekst, powiązała pamięć z narracją, przesłaniając źródłowe - i nieustanie przywoływane w zeznaniach - doświadczenie rozmaitych form aktów wzrokowych. Wysoka częstotliwość odwoływania się do pracy wzroku charakteryzuje zwłaszcza teksty dotyczące „licznej i różnorodnej grupy podmiotów, które umożliwiają i czerpią zyski z traumatyzującej przemocy, nie biorąc w niej bezpośredniego udziału"4 - czyli tzw. bystanders.

Badania historyczne i krytyczne, gdy zajmują się zróżnicowaniem funkcjonalnym „trzeciej grupy”, mimo że często posługują się terminami związanymi z różnymi formami czynności wzrokowych, nie różnicują znacząco pojęć, traktując „obserwatorów”, „patrzących” czy „gapiów” synonimicznie. Tymczasem rozwijające się od co najmniej trzydziestu lat visual culture studies zaznaczyły swą obecność na rynku badań nad kulturą wystarczająco dobitnie, by poważnie potraktować opracowywane w obszarze tej interdyscypliny koncepcje spojrzenia i różnych wariantów widzenia. Rozpodobnienie znaczeń i wysublimowanie terminologii stosowanej do opisu relacji kontaktu wzrokowego między aktorami pola przemocy może - jak sądzę - wyjaśnić wiele wątpliwości w kwestii stopnia podmiotowości, sprawczości, zdolności poznawczych i możliwości komunikacyjnych analizowanej grupy, prowadząc do bardziej zróżnicowanych rozpoznań, potrzebnych w sytuacji coraz wyraźniej rozbudowanej i zniuansowanej wiedzy o działaniach postronnych ${ }^{5} \mathrm{w}$ czasie wojny.

Gdy w 1992 roku Raul Hilberg zaakcentował w języku studiów nad Holokaustem kategorię bystanders, podzielił ją na helpers (pomagających), beneficiaries (czerpiących zyski) i - właśnie - observers (obserwujących) ${ }^{6}$ (niektóre przekłady jego książki podążyły tym tropem i w miejsce kłopotliwego

4 Zob. M. Rothberg Trauma Theory, Implicated Subjects, and the Question of Israel/Palestine, https://profession.mla.hcommons.org/2014/05/02/trauma-theory-implicated-subjects-andthe-question-of-israelpalestine/ (20.01.2018).

5 Posługuję się w niniejszym tekście terminem „postronny" jako alternatywnym przekładem kategorii bystander, dołączając do tych (zwł. Elżbieta Janicka, Tomasz Żukowski, Jan Tomasz Gross), którzy kwestionują stawianie znaku równości między bystanders a świadkami. Termin "świadek" rezerwuję dla tych spośród „społeczności dopełniającej scenę przemocy”, którzy podejmują wysiłek świadczenia. Powody wyjaśniam w tekście Od świadków do postronnych. Kategoria bystanders i analiza „podmiotów uwikłanych" publikowanym w tomie po konferencji Świadek: jak się staje, czym jest?, 11-12 stycznia 2018, Kraków, Wydział Polonistyki UJ.

6 Zob. R. Hilberg Perpetrators Victims Bystanders: The Jewish Catastrophe, 1933-1945, HarperCollins, New York 1992, wyd. polskie Sprawcy, ofiary, świadkowie: zagłada Żydów 1933-1945, przeł. J. Giebułtowski, Centrum Badań nad Zagładą Żydów, Wydawnictwo Cyklady, Warszawa 2007, s. 310 . 
w translacji angielskiego terminu wprowadzały pojęcie "obserwatorów") ${ }^{7}$. Być może najdobitniej zachęcał do poważnego potraktowania terminów skopicznych Paul A. Levine, gdy w The Oxford Handbook of Holocaust Studies opisywał w części dotyczącej „protagonistów” tę, jak twierdził, najbardziej problematyczną kategorię, którą określał terminem on-lookers. Mimo problemów z wielkością tej grupy (najliczniejszą wśród wyróżnionych przez Hilberga), jej różnorodnością (budowały ją jednostki, grupy społeczne, w końcu instytucje i państwa) i motywacją (pomagający, denuncjujący, korzystający, umożliwiający etc.) „badacze poczynili w ostatnich dekadach znaczne postępy w badaniach nad tym obszarem Zagłady - pisał Levine. Ich działania jednak ujawniają potrzebę nowej terminologii. Dziś, gdy badacze ustalili, do jakiego stopnia prześladowania, szaber, deportacje i mordowanie Żydów były jawne, w wielu przypadkach publicznie, termin on-looker wydaje się bardziej precyzyjny niż bystander, jeśli chcemy oznaczyć tych, którzy nie zapobiegli powyższym zdarzeniom lub nie interweniowali w nie. Termin on-looker akcentuje sam akt i topograficzną bliskość bycia naocznym świadkiem oraz sugeruje większą odpowiedzialność wobec efektu tego działania, wliczając w to szerszą skalę reakcji emocjonalnych i większy wpływ na sprawców niż bardziej neutralnie brzmiący bystander"8.

\section{Obserwator, patrzący, widz, gap}

O ile można zrozumieć, czemu badania historyczne są niewrażliwe na wieloznaczność terminów skopicznych, to bardziej zaskakujące jest, że sama kultura wizualna jak dotąd nie zauważyła potencjału własnych narzędzi w odniesieniu do badań nad Zagładą9. Tymczasem sporo wiadomo na temat wagi zmysłu wzroku w gospodarce sensorycznej nazizmu - począwszy od estetyzacji ciała

7 Zob.np. R. Hilberg Pachatelé, oběti, diváci.Židovská katastrofa 1923-1945, przeł. M. Troševa, Argo, Praha 2002.

8 P. Levine On-lookers, w: The Oxford Handbook of Holocaust Studies, ed. by P. Hayes, J.K. Roth, Oxford University Press, Oxford 2010, s. 158. Termin onlookers pojawia się też w późniejszej o dwa lata, zainspirowanej wezwaniem Levine'a, analizie Looking at the Onlookers and Bystanders pod redakcją Henrika Edgrena (Zob. Looking at the Onlookers and Bystanders. Interdisciplinary Approaches to the Causes and Consequences of Passivity, ed. by H. Edgren, The Living History Forum, Stockholm 2012, s. 21).

9 We wstępie do The Right to Look: A Counterhistory of Visuality (Duke University Press, Durham 2011) jeden z głównych teoretyków ruchu visual culture, Nicholas Mirzoeff, przyznaje otwarcie, że dyscyplina ta ma kłopot z podejmowaniem trudnych tematów. 
i ubioru, poprzez spektakl publicznie demonstrowanej siły, po zaangażowanie nowych wizualnych technologii w służbie ideologii ${ }^{10}$. Żaden zmysł nie był też tak obsesyjnie kontrolowany w procesie Zagłady, jak wzrok. „W fazie koncentracji, deportacji i mordów sprawcy starali się izolować ofiary od reszty ludności”, ,krzywo patrzono na obserwatorów, ponieważ, zwłaszcza w przypadku Niemców, przyglądanie się uchodziło za rzecz nieprzyzwoitą", ,bez względu na to, czy widok był odpychający, czy atrakcyjny, wszelkie pogłoski [...] drażniły”, „administracja niemiecka wydawała polecenia, by mieszkańcy pozostali w domach przy zamkniętych oknach i opuszczonych zasłonach”, „niemiecki inspektor armii narzekał, że żołnierze stali się mimowolnymi świadkami operacji”, „,w wielu przypadkach gapiów nie można było powstrzymać”, „na Korfu obserwatorzy przyglądali się akcji na ulicy i z balkonów”, na Węgrzech "gdy węgierscy żandarmi prowadzili Żydów do pociąów, na ulicy stali śmiejący się na ich widok mieszkańcy miasta”, w Żytomierzu „egzekucji dwóch Żydów przyglądali się licznie zgromadzeni na dachach żołnierze"11.

Niewątpliwie wyjątkiem od tego przeoczenia jest praca Ernsta van Alphena Caught by History ${ }^{\mathbf{1 2}}$ z 1997 roku oraz kolejna, zatytułowana Art in Mind $(2005)^{13}$, w której pojawia się analiza wizerunków i wizualnych powidoków w odniesieniu do Zagłady, nie ma tu jednak mowy o różnych formach podmiotowości wytwarzanych w wyniku odmiennych czynności skopicznych. W tym kontekście tekst Elżbiety Janickiej Pamięć przyswojona angażujący w analizę relacji ofiar i postronnych klasyczne terminy kultury wizualnej, czyli pojęcia „spojrzenia” (gaze), , obserwatora” oraz „panoptykonu”,jest pionierska ${ }^{14}$, a za-

10 Wszystkie te wątki można znaleźć w niedawno wydanej pracy Jana Borowicza (Nagość i mundur. Ciało w filmie Trzeciej Rzeszy, Książka i Prasa, Warszawa 2015). Fascynację nazistów fotografią (czego dowodem może być np. wprowadzanie nauki fotografowania do szkół Hitlerjugend) bada niemiecka kuratorka Petra Bopp (zob.np. tejże Fremde im Visier. Fotoalben aus dem Zweiten Weltkrieg, Kerber Verlag, Bielefeld 2009).

11 W oryginale: isolate from public view. Zob. R. Hilberg Perpetrators Victims Bystanders..., s. 215. W wersji polskiej: R. Hilberg Sprawcy, ofiary, świadkowie..., s. 314-316.

12 Zob. E. van Alphen Caught by History, Stanford University Press, Stanford 1997.

13 E. van Alphen Art in Mind: How Contemporary Images Shape Thought, University of Chicago Press, Chicago 2005). Zob. polski przekład fragmentu: E. van Alphen W pułapce wizerunków, przeł. R. Sendyka, "Teksty Drugie" 2009 nr 5, s. 124-143. Zob. także analizę: M. Bal Of What One Cannot Speak. Doris Salcedo's Political Art, University of Chicago Press, Chicago 2010), w której krytyczka omawia sztukę Doris Salcedo, korzystając z koncepcji świadka i narzędzi analizy wizualnej.

14 E. Janicka Pamięć przyswojona. Koncepcja polskiego doświadczenia zagłady Żydów jako traumy zbiorowej w świetle rewizji kategorii świadka , „Studia Litteraria Historica”2014-2015 nr 3/4. 
proponowany tam ruch w stronę badań wizualnych, jak sądzę, bez wątpienia wart kontynuacji ${ }^{15}$. Chciałabym więc zastanowić się, czy między patrzącymi na Zagładę i widzącymi jej zdarzenia można postawić znak równości? Czy widz i widzący jest tą samą osobą? Czy obserwator i gap postrzega podobnie? Innymi słowy, poniższe rozważania są próbą kalibrowania terminów używanych do opisu postronnych i jednocześnie to propozycja szerszego zaangażowania gotowej już i dostępnej metodologii z zakresu badań nad kulturą do pogłębienia badań socjohistorycznych i badań nad Zagładą.

\section{a. Patrzący, widzący}

„Tłumaczka Ewa”: Pan się pyta, dlaczego pan jest taki smutny?

Henryk Gawkowski: Bo - dlatego że - widziałem, że to ludzie idą na śmierć ${ }^{16}$

Czasownik „patrzeć”, notowany od XV wieku, oznacza w podstawowym swym znaczeniu „kierowanie oczu na kogoś, coś”.,Widzieć"17 to „dostrzegać, zauważać za pomocą wzroku". Pozornie oba czasowniki opisują tę samą, podstawową czynność działania aparatu wzrokowego. A jednak - istnieje między nimi znacząca różnica. Powiedzenie „patrzysz a nie widzisz” pozwala rozróżnić znaczenia podświadomie konotowane przez użytkowników języka. „Patrzący”

$15 \mathrm{Z}$ analizą Janickiej z podrozdziału Pamięć nieprzyswojona. Dekonstrukcja warto dyskutować. Pomysł opisu relacji społecznych w drugowojennej Polsce za pomocą koncepcji panoptykonu i "społeczeństwa panoptycznego" teoretycznie konceptualizuje sceny tworzące "topos literatury zagładowej" opisywany m.in. w znanym tekście Michała Głowińskiego: uciekinierzy z getta byli „ "na widoku”, ,"uchodzili spod oka szantażysty”, ",czuli na sobie czyjeś oczy" (M. Głowiński Oczy donosiciela "Zagłada Żydów” 2006 nr 2, s. 854-855). Moje zastrzeżenia wzbudza uogólnienie "panoptycznej przemocy wzrokowej" w esencjalną cechę wojennego społeczeństwa, "opresywne" rozumienie terminu "prawa do spojrzenia" (droit de regard) za analizą Pierre'a Bourdieu (La domination masculine, 1998; pol. Męska dominacja, przeł. L. Kopciewicz, Oficyna Naukowa, Warszawa 2004) z pominięciem emancypacyjnych sensów proponowanych we wcześniejszym tekście Derridy, któremu przypisuje się autorstwo terminu (zob. M.-F. Plissart Droit de regards [fotopowieść]. Wstęp: J. Derrida, Editions du Minuit, Paris 1985; zob. też komentarz w N. Mirzoeffa The Right to Look...). Janicka eksploatuje również przemocowy charakter spojrzenia (tak jak termin ten funkcjonował u Sartre'a, Lacana i u teoretyków wczesnej fazy visual culture), który został wielokrotnie już zakwestionowany i zastąpiony bardziej niuansowanymi wartościami. Jw., rozdział 41 (cz. 1).

17 Znaczenia obu słów podaję za: Słownik etymologiczny języka polskiego, red. W. Boryś, Wydawnictwo Literackie, Kraków 2012, s. 418, 691. 
- słowo o niepewnej etymologii w języku polskim - sugeruje więc po pierwsze bierną, pozbawioną nastawienia poznawczego, fizjologiczną czynność „działania oczu": wzrok omiata scenę, notuje jej elementy, wyższe funkcje kognitywne są wyłączone, nie opracowują dostarczanych danych. „Biedny chrześcijanin patrzący na getto" bez wątpienia nie może być świadkiem - może jedynie - jak trafnie to zidentyfikował Miłosz - obawiać się nadejścia sędziego, któremu nie będzie miał nic do powiedzenia. Nic nie powie, bo nie wie, bo nie widział.

Ten, kto widzi (słowo notowane w języku polskim o stulecie wcześniej niż „patrzeć”), „dostrzega, zauważa za pomocą wzroku”. Od tego słowa pochodzi przymiotnik „widomy” (a dalej: „wiadomy”: widzieć, jak w wielu innych językach $^{18}$, spokrewnia się więc z „wiedzieć”). Widzący - rozpoznaje i rozumie to, co zobaczył. Słowa „widziadło”, ,jasnowidz”, (pamiętamy też „Widzącego z Lublina") - sugerują nawet więcej: widzenie może przenikać materialny widok, dosięgać ukrytego sedna, przekraczać porządek empiryczny.

\section{b. Oglądający, spoglądający, podglądający}

"Chłopi z Treblinki”: Jak się szło za pługiem, to się czasem spojrzało.

Barbara Janicka: Wrasadzie chcieli, żeby pracować ze spuszczonymi oczami ?9 $^{19}$

„Spoglądać”, czyli „rzucać okiem”20, to XVIII-wieczne słowo pochodzące od starszego, XV-wiecznego „oglądać"21. Oglądający patrzy z różnych stron, przypatruje się; ma więc czas i sposobność, by zbliżyć się do obiektu (jego stopień uruchomienia jest wyższy niż wszystkich pozostałych kategorii, o których będzie tu mowa). Jego działanie sugeruje nastawienie poznawcze, przydatne w kontekście prawniczym („dokonywać oględzin”). Od „oglądającego” można się więc spodziewać szczegółowego i metodycznego raportu, wyczerpującego opisu - nie ma jednak pewności, że opisujący dokona rozpoznania i zaproponuje wnioski, nie jest to jego zadaniem. Czasownik pochodzi od prasłowiańskiego *ględati - to czasownik wielokrotny od czasownika stanu

18 M. Jay Downcast Eyes: The Denigration of Vision in Twentieth-Century French Thought, University of California Press, Berkeley 1994, s. 2. Shoah, reż. Claude Lanzmann, rozdział 24 (cz. 1). Słownik etymologiczny języka polskiego, s. 569. 
*ględěti - „patrzeć”. Wzrok oglądającego ześlizguje się z obiektów podobnie więc jak oczy patrzącego, który nie widzi. Efekt działań oglądającego przynajmniej dostarcza jednak danych.

Podglądający natomiast, który rzuca ukradkowe spojrzenie, sam nie chcąc być widzianym, naruszający prywatność przedmiotu swojej aktywności, dodaje do tego zestawu kontrpoznawczych cech naddatek przemocy (rzut oka jako rzut $w$ kogoś) i konotację rozkoszy, przyjemności seksualnej, przekraczania zakazu, napawania się widokiem nie-dla-mnie, widokiem przejętym bez zezwolenia. Działanie woli podglądacza nie ulega wątpliwości, jego podmiotowe istnienie jest jednak niepełne, skoro musi pozostać w ukryciu i dbać o nieujawnienie się.

Ten, kto spogląda lub podgląda, ma mniej czasu - jego czynność jest krótsza. "Spoglądać” to „rzucać okiem"22 - interesujące w tym wariancie jest sugerowanie kontaktu obiektu i fragmentu działającego ciała, zgodnie ze starożytnymi przekonaniami o zdolności oka do ekstramisji (oko jako punkt, z którego wysuwa się „niby-promień” dotykający rzeczywistości). O ile patrzący nie jest w pełni sprawczym podmiotem, skoro pozbawiony jest wyższych funkcji poznawczych, skoro przypomina nie-ludzki aparat, w którym nie zamyka się migawka, to oglądający jest jak rejestrująca ruchoma maszyna. Podglądacz to z kolei ukryta kamera, która rejestruje to, na co została skierowana. Jej zapis nie będzie poddawany rozumieniu, posłuży jedynie do libidalnego zaspokojenia.

\section{c. Widz}

Claude Lanzmann: Il était aux premières loges pour voir tout-ça là-bas.

Barbara Janicka: Pan spojrzy tam. Widziat pan wszystko to jak w loży, to co tam sie dziato?

Czesław Borowy: No naturalnie, że widziałem. ${ }^{23}$

Polskie społeczeństwo umieszczone w „pierwszej loży” w teatrze zagłady można rozważać jako zbiorowość widzów. Ta teza organizuje dyskusję Grzegorza Niziołka nad polskim teatrem powojennym - praca ta jednocześnie jest oryginalnym wstępem do analizy wizualnej Holokaustu. Niziołek przyjmuje

Tamże, s. 569.

Shoah, reż. Claude Lanzmann, rozdział 23 (cz. 1). 
Hilbergowską tezę o w pełni „widzialnym charakterze Zagłady" ${ }^{24} \mathrm{i}$ buduje na tej podstawie radykalne wnioski: postronnych można zdefiniować jako widzów, dla których „żydowskie cierpienie staje się wyłącznie spektaklem"25.

Widz to "ten, który się czemuś przygląda, nie biorący w czymś udziału”26. Termin ten wywodzi się z tego samego źródłosłowu, co „widzieć", można więc widzowi przypisywać zdolność rozpoznawania i zrozumienia widoku. Interesującym naddatkiem jest natomiast konotacja instytucjonalna. W językach wschodniosłowiańskich słowo to przynależy do dawnej terminologii sądowej (dotyczy urzędnika sądowego, asesora, kogoś, kto ma obowiązek przesłuchać świadka), którą jednak dziś zdominowały sensy związane z teatrem i oglądanym w nim spektaklem.

Łaciński spectator pochodzi z czasownika spectare i oznacza kogoś, kto ogląda publiczne wydarzenie. Wszelkie podane jak dotąd konotacje łączące widza z instytucją czynią z niego osobę uczestniczącą w działaniu projektowanym przez nadrzędny podmiot. Widz - zgodnie z XIX-wiecznymi konotacjami jest pasywny, powodowany przyjemnością, ukryty w ciemności sali teatralnej (tu spokrewnia się z podglądaczem), bierny, nieuważny, ulega obrazom, poddaje się działaniom reżyserowanym przez innych, jest izolowany od centrum zdarzeń, pozbawiony więc - znów - pełnej sprawczości²; w XX wieku Guy Debord dodał do tego zestawu jeszcze uległy konsumeryzm ${ }^{\mathbf{2}}$. Wedle rozpoznania Jacques'a Rancière'a „bycie widzem oznacza patrzenie na spektakl. A patrzenie jest rzeczą złą z dwóch powodów. Po pierwsze, patrzenie jest przeciwieństwem poznania. Oznacza odnoszenie się do zjawiska bez znajomości warunków produkcji tego zjawiska lub ukrytej w nim rzeczywistości. Po drugie patrzenie uchodzi za przeciwieństwo działania"29. Widz włączony jest więc w plan instytucji, która narzuca mu swoje zasady postępowania, skrypt akcji lub raczej - jej zaniechania. Jak pisze Niziołek, przyjęcie „reguły

\footnotetext{
24 G. Niziołek Polski teatr Zagłady, Instytut Teatralny im. Z. Raszewskiego, Wydawnictwo Krytyki Politycznej, Warszawa 2013, s. 48.

27 Zob. J. Crary Techniques of the Observer: On Vision and Modernity in the 19th Century, The MIT Press, Cambridge 1992, s. 3.

28 G. Debord The Society of the Spectacle, trans. D. Nicholson-Smith, Zone Books, New York 1994; pol. Społeczeństwo spektaklu oraz Rozważania o społeczeństwie spektaklu, przeł. M. Kwaterko, PIW, Warszawa 2006.
}

29 J. Rancière Widz wyemancypowany, przeł. A. Ostolski, ,"Krytyka Polityczna” 2007 nr 13, s. 311. 
teatralności” powoduje, że „świadek przestaje być świadkiem, staje się widzem, nie musi więc podejmować działania" ${ }^{\text {"30 }}$.

Podsumowując powyższe, widz nie jest zdolny do złożenia w pełni osobistych, obiektywnych zeznań, do jakich zobowiązany jest moralnie świadek: bierze udział w działaniach zaprojektowanych nie przez siebie, jest trenowany w bierności, upodobnia się do innych uczestników zdarzenia, infuzja afektów wyklucza obiektywizm (umożliwia jednak - co ważne - identyfikację z tym, kto postawiony został na scenie). To pierwsze dyskutowane określenie, które ma formę rzeczownika (zamiast imiesłowu odczasownikowego czynnego) na marginesie więc notuję zastanawiającą kwestię określania płci widza: o ile poprzednie formy mogły dostosowywać się do indywidualnej płci podmiotu (formy żeńskie i męskie były podobnie poprawne i możliwe) - żeński odpowiednik widza nie istnieje $\mathrm{w}$ języku polskim ${ }^{31}$. Widz staje się $\mathrm{w}$ tym świetle rodzajem funkcji, w którą nie da się wpisać konkretnego podmiotu z jego osobniczymi, swoistymi cechami. Widz jest więc ontologiczną fikcją o tyle, że jest jedynie konstrukcją projektującej go instytucji.

\section{d. Gap}

Abraham Bomba: maybe it's not nice to say, but I will say it. Most of the people, not only the majority, but ninety-nine percent of the Polish people when they saw the train going through - we looked really like animals in that wagon, just our eyes looked outside - they were laughing, they had a joy. ${ }^{32}$ To nie jest przyjemne, ale opowiem. Przytłaczająca większość Polaków, kiedy widzieli przejeżdżający pocią - byliśmy w tym wagonie jak zwierzęta, widać było tylko nasze oczy - śmieli się, śmieli, cieszyli się. ${ }^{33}$

Gap to być może najbardziej zastanawiający termin określający podmiot skopiczny: jego odmienność polega na zatraceniu (albo przynajmniej osłabieniu) funkcjonalności tego rzeczownika w formie liczby pojedynczej. Innymi

G. Niziołek Polski teatr..., s. 52. Zob. też. B. Engelking Polacy-gapie Zagłady, "Więź” 2011 nr 8/9.

Co interesujące, w języku angielskim istniał wariant żeński widza: spectatress, a także bardziej poprawna forma spectatrix - termin używany już od XVII stulecia. Dziś dominuje jednak męski spectator. Zob. http://www.etymonline.com/index.php?term=spectator (20.01.2018).

Shoah, reż. Claude Lanzmann, rozdział 31 (cz. 1).

C. Lanzmann Shoah, przeł. M. Bieńczyk, Oficyna Wydawnicza Novex, Koszalin 1993, s. 41. 
słowy, o ile bez kłopotu akceptujemy słowo "gapie”, „gap” wydaje się formą sztuczną (zwłaszcza w mianowniku). Funkcjonuje natomiast pokrewna forma, rzeczownik „gapa”, określający kogoś, kto się „zagapił”, przeoczył coś. Forma pojedyncza stosowana była dawniej dla określenia „głupca, zwłaszcza tępego, naiwnego" - postać z komedii i wywodziła się ze słowa, które oznaczało „wronę". Forma mnoga "gapie" ustaliła się w drugiej połowie XIX wieku jako import z języka niemieckiego (czasownik „gaffen” oznacza „gapić się") $)^{34}$. Negatywna konotacja nie ulega wątpliwości - nikt sam siebie chętnie nie określi terminem "gap": podmiotowość ta nie jest więc brana pod uwagę przy autoidentyfikacji.

Niedomaganie formy liczby pojedynczej tego rzeczownika pozwala wnioskować, że nie można być gapiem w pojedynkę: to czynność, którą wykonujemy wraz z innymi, gdy stajemy się częścią tłumu „przypatrującego się bezmyślnie"35. Gapie zbierają się spontanicznie, wokół niespodziewanego zdarzenia, dziejącego się publicznie, powoduje nimi ciekawość, czerpią przyjemność z obserwacji zdarzeń wyjątkowych, także drastycznych. Ładunek afektywny jest tu najwyższy, indywiduacja podmiotowa zachodzi w najmniejszym stopniu (skoro możliwa jest wyłącznie identyfikacja zbiorowa), potrzeba zrozumienia - minimalna, dominuje motywacja libidalna, celem jest czerpanie przyjemności, poczucie dreszczu wobec bliskości zagrożenia, zneutralizowanego o tyle, że dotknęło „nie-mnie”.

Ten wariant podmiotu skopicznego na scenie Zagłady świetnie ilustruje tezy, rozwijane dziś m.in. przez Michaela Rothberga i Mary Fulbrook ${ }^{36}$, o nagłym, sytuacyjnym i kontekstowym stawaniu się podmiotów sceny przemocy. Gap różni się bowiem od widza, choć obaj oglądają w pewnej zbiorowości publiczne wydarzenie. Ten pierwszy jednak „pochwycony jest” przypadkiem i jego decyzyjność jest ograniczona - może go „wchłonąć tłum”; ten drugi o ile do teatru chadza się dobrowolnie - podejmuje suwerenną decyzję przyjęcia pozycji spectatora. Konsekwentnie więc o społecznościach wplątanych w scenę przemocy nie można bez dodatkowych zastrzeżeń powiedzieć, że były „widzami” Zagłady: potrzebny byłby tu inny rzeczownik. Analiza Niziołka potwierdzająca funkcjonalność metafor teatralnych wymaga - jak widać dodatkowej dyskusji nad dystrybucją terminów określających najogólniejsze

34 s. 407.

35 JW., s. 408.

36 Zob. M. Rothberg Trauma Theory..., także M. Fulbrook Bystanders: Catchall Concept, Alluring Alibi or Crucial Clue?, w: Probing the Limits of Categorization... 
ramy tego projektu, którą zresztą projektował sam autor zastanawiając się, czy „polska kultura powojenna jest kulturą «świadków», «obserwatorów», czy wręcz «gapiów»"37.

Zbiorowisko gapiów holokaustowej przemocy zespala nie tyle „nadrzędna instytucja” („reżyser”,,,scena” zdarzenia), co obiekt obserwowany przez tłum: jeśli stan obiektu przestanie oddziaływać na afekty zgromadzonych wokół, tłum się rozejdzie. Inaczej również niż podczas tradycyjnie pojmowanego spektaklu - sytuacja nie ma uprzedniego skryptu i jej rozwój jest nieprzewidywalny. W tym sensie gap jest potencjalnie narażony na niebezpieczeństwo (jeśli skupiona na obiekcie kotwiczącym uwagę przemoc zmieni swój kierunek), widz funkcjonuje w warunkach bezpiecznych. I o ile poprzednie omówione tu warianty aktora sceny zbrodni sugerowały kogoś oddalonego od obserwowanego obiektu, to termin "gap" konotuje stosunkowo niewielki dystans i jawny kontakt wzrokowy.

Określanie postronnych jako gapiów definiuje zatem podmiot zbiorowy, konstytuowany sytuacyjnie i na krótki czas, niezdolny do bardziej ustrukturowanego działania, pozbawiony sprawczości poza podejmowaniem ograniczonych czynności (patrzenie, okrzyki, gesty), zdolny natomiast do odczuwania (przyjemności i strachu), lecz nie do analizy i dawania świadectwa. Gap, bez wątpienia, patrzy i zwalnia się w rezonansie afektywnym z tłumem z zobowiązania do widzenia.

\section{e. Obserwator}

Abraham Bomba: At the other side of the tracks I saw more trains standing there and I was watching through and saw about eighteen - twenty, maybe more, trains going away. And after about an hour or so I saw the trains coming there but without the people. ${ }^{38}$

$\mathrm{Na}$ torach obok spostrzegłem inne pociągi. Obserwowałem... i spostrzegłem około osiemnastu, dwudziestu wagonów, może więcej, odjeżdżających razem. I gdzieś po godzinie zobaczyłem, jak wagony wracają, ale bez ludzi. ${ }^{39}$

G. Niziołek Polski teatr..., s. 53.

Shoah, reż. Claude Lanzmann, rozdział 33 (cz. 1). 
Najbliższy funkcji świadka byłby być może obserwator (termin, przypomnę, proponowany przez Hilberga). Termin pochodzi z łacińskiego observare zauważać (observatio - oglądanie czegoś). Obserwator podejmuje czynność uważnego, wnikliwego postrzegania. Definicje ujmują go jako postać zdystansowaną, racjonalną, nastawioną badawczo, analitycznie: naukowca badającego w zaplanowany sposób dane zjawisko, cierpliwie, systematycznie i długo. Obserwator rejestruje zmiany, próbuje interpretować zbierane dane. Z tą pozycją łączy się więc najwyższy - jak dotąd - stopień upodmiotowienia: obserwator jest sprawczy, jego kompetencje poznawcze są najwyższe, jest godny zaufania. Jego scjentystyczne nastawienie wyklucza afektywne zaangażowanie. Wtedy więc, gdy określamy postronnych Zagłady jej obserwatorami, mamy na myśli tych, którzy widzieli, rozumieli to, co widzą, potrafili rejestrować i interpretować wydarzenia, za cenę jednak dystansowania się od obiektów obserwacji i wychładzania możliwych odruchów empatii.

Wydaje się, że obserwator to jedyny wariant podmiotu skopicznego obdarzony autonomią i pełnią władz poznawczych. A jednak i tu - okazuje się - przydaje się ostrożność: Jonathan Crary, w wyczerpującej analizie pozycji XIX-wiecznego obserwatora, przypominał o łacińskiej konotacji łacińskiego observare ze znaczeniami „zachowywać”,„,szanować” np. zwyczaje.„Obserwator to pilnujący porządku, ustawy albo zwyczajów, ściśle je wypełniający"40. Obserwator przestrzega zatem protokołu. Poddaje się narzucanej normie. Może to być niepisana zasada oddzielenia od losu żydowskiego, „niemieszania się”, „nienagażowania się", sprzyjająca w ostatecznym rozrachunku sprawcom i ich pomocnikom - wydaje się, że to termin, który potencjalnie mógłby być stosowany najczęściej wobec konkretnych opisów sytuacyjnych zachowań postronnych w wojennej Polsce.

"Obserwator - pisał Crary - to ktoś, kto widzi i - co istotniejsze - ktoś kto widzi w ramach zdefiniowanych uprzednio możliwości, ktoś, kto jest pochwycony w system konwencji i ograniczeń". Jego możliwości predefiniuje „laboratoryjna aparatura potrzebna do obserwacji” - a szerzej - „heterogeniczny system relacji dyskursywnych, społecznych, technologicznych i instytucjonalnych"41. Obserwator więc - mimo swych scjentystycznych zdolności - może okazać się niewydolny w obliczu zdarzeń wykraczających „poza normę”, wobec zjawisk „nie do pojęcia”. Jeśli zatem przyjmiemy, że Ho-

\footnotetext{
40 Hasło obserwator, w: Słownik ilustrowany języka polskiego, red. M. Arct, Wydawnictwo M. Arcta, Warszawa 1929, s. 430.

41 J. Crary Techniques of the Observer..., s. 5-6.
} 
lokaust zniósł wszelkie poprzedzające go „systemy relacji”, to w radykalnym ujęciu można powiedzieć, że - paradoksalnie - Zagłada będzie zdarzeniem „bez obserwatorów”, tak jak jest „zdarzeniem bez świadków”42.

\section{$* * *$}

Terminy przekształcone w pojęcia kultury wizualnej w odniesieniu do pola społecznego Zagłady pozwalają na precyzyjne nazywanie różnorodnych relacji: patrzenie na Zagładę i widzenie Zagłady, bycie jej widzem, podglądaczem, obserwatorem i gapiem znaczy co innego. Różnice znaczeniowe wprowadzane przez proponowane powyżej kategorie są tak znaczące, że stosowanie ich jako synonimów może być jedynie kontrproduktywne, zwłaszcza jeśli zaakceptujemy tezę o naddeterminacji skopicznej (w sensie kontroli lub przeciwnie, hiperbolizacji bodźców wzrokowych) wydarzeń Holokaustu. Dokładniejsza analiza rzeczowników określających różne warianty podmiotu skopicznego uświadamia również czynnościowy charakter wymiany wzrokowej. Spojrzenia jednak mają różny charakter, nie tylko dyscyplinują i uprzedmiotawiają swoje obiekty: efektów tych czynności jest o wiele więcej (więcej również, niż zdołałam to powyżej przedstawić; zapoczątkowaną w tekście analizę można prowadzić dalej, zwłaszcza badając strategie wzrokowe ofiar i sprawców oraz wielokierunkową sieć wymian między możliwymi pozycjami na scenie przemocy oraz sytuacyjną przechodniość skopicznych podmiotowości - mam tu na myśli płynność owych pozycji, które mogą dotyczyć zarówno sprawców, jak i ofiar czy postronnych).

W kontekście dalszego rozwoju badań nad sceną Zagłady, ludobójstwa i najszerzej - aktów naruszania prawa do życia - szczególnie przydatna okazuje się możliwość precyzyjniejszego definiowania za pośrednictwem powyżej dyskutowanych koncepcji wariantów podmiotowości bystanders (postronnych) - zależnej, co teraz stało się ewidentne - od zewnętrznych relacji instytucjonalnych, społecznych, dyskursywnych, technologicznych, od warunków czasowych i przestrzennych, w tym od dystansu wobec obiektu, od emocjonalnej identyfikacji, od typu procesów poznawczych, od możliwości podejmowania aktów wolicjonalnych, od inwestycji afektywnych. Postronni są zawsze po jakiejś stronie. Nieneutralni, „nawet jeśli są odwróceni tyłem

42 Zob. D. Laub Zdarzenie bez świadka: prawda, świadectwo oraz ocalenie, przeł. T. Łysak, „Teksty Drugie" $2007 \mathrm{nr} 5$. 
i zajęci swoimi sprawami"43, stają się czynnymi postaciami na scenie przemocy, która przekształca się tym samym w pole widzialności - jego wymiar, warianty i właściwości pozostają wciąż do opisania. Obserwacja relacji skopicznych pozwala na inne i nowe zrozumienie dystrybucji ról w tym obszarze. Postronni, będąc postaciami poruszającymi się w jego wnętrzu, nie są w pełni autonomicznymi podmiotami - ułomność ich suwerenności ma różne warianty i jest zmienna w skali, analiza wizualna pozwala dokładniej szacować jej ubytki. Na świadków można powołać jedynie tych, którzy widzieli. Widzieli, jak ludzie idą na śmierć. Patrzyli na nich. Powiedzieli innym, co widzieli. Nie zapomnieli.

\section{Abstract}

\section{Roma Sendyka}

JAGIELLONIAN UNIVERSITY (CRACOW)

Bystanders as Visual Subjects: Onlookers, Spectators, Observers, Gawkers

In this essay, bystanders are analysed not through the lens of topography (i.e. geographical closeness to the events expressed in the term "by-stander"), but as visual subjects. Concerning those who witnessed the Holocaust, bystanders are linked with various types of scopic activities, especially negative ones: they are often generalized as passive onlookers, as "those who stare" with libidinal pleasure [Polish: gapie; French: badauds; German: Schaulustige]. It is surprising, however, that the frequent use of scopic vocabulary is not necessarily associated with developed theoretical concerns. The recent visual (iconic) turn, however, has provided a refined and varied set of tools for analysing the faculty of seeing. Therefore, it is no longer plausible to discuss the processes of seeing without precise conceptualizations. Instead of employing visual terms merely as synonyms, this essay challenges and restructures available categorizations for bystanders as those acquiring knowledge through the sense of sight.

\section{Keywords}

bystander, witness, onlooker, visual subject, viewer, observer, gawker, Holocaust

43 J.T. Gross Sprawcy, ofiary i inni, „Zagłada Żydów. Studia i Materiały” 2014 nr 10, s. 885. 